\title{
MARKET ORIENTATION OF BUSINESS SCHOOLS AND DEVELOPMENT OF PROFESSIONAL COMPETENCIES OF STUDENTS IN THE TOURISM BUSINESS
}

\author{
Maja Rosi, Faculty of tourism, Maribor \\ Milan Jurše, Faculty of Economics and Business, Maribor
}

\begin{abstract}
Recent trends of spreading of market globalization, technological progress, internationalization, privatization and other relevant changes are strategically changing the context in which all institutions of society operate and prosper. The higher education sector is also affected, and, in particular, the business education has to be better aligned with these external realities. In this dynamic and changing environment, students, businesses and other stakeholders require knowledge and skills that will provide them with competency in relation to the current economic situation and technological advances. Tourism sector and whole economy increasingly depend on contemporary knowledge that provides appropriate job competency to students and competitive advantage to the providers of services. Adjustment of public higher education institutions is important for enhancing their market position in increasingly competitive market for business education. There is an increasing number of private business schools that have emerged recently, also in the field of tourism that have seen their great potential for business success and earnings in the increasingly competitive business education market, framed by a very dynamic and competitive environment of business education. In addition, business schools have to deal with the trend of shrinking budgetary (public) funding of their operation, which forces them to search for additional funding by providing new educational offerings and strengthening of their market orientation. In the debate about the future of tourism education, there lies a gap between the requirements of the curriculum and the expectations of the industry, which argues that higher education has to serve the tourism of the future - that is to prepare students for a more active role in tourism organizations and in their search for improvements and adaptation to different competitive circumstances. Does business schools' curriculum follow the development of key recent trends in the industry? The main objective of this paper is to identify the key aspects of the dynamic adaptation of university business schools and to elaborate on the possible linkage between the development of professional competences of students in the field of tourism and the professional requirements of organizations in this industry. We will use the comparative method (overview and comparison of tourist programs of selected faculties in selected countries of the former Yugoslavia, review and comparison of their programs regardless of any possible accreditation) and benchmarking analysis that will help us identify differences in achieved professional student competencies in selected faculties and compare them against achieved professional student competencies of selected, leading faculties in central Europe in the field of tourism.
\end{abstract}

Keywords: Graduate professional competence, Tourism education, Market orientation of public higher education institutions, Globalization, Privatization of higher education 


\section{TRŽIŠNO USMERENJE POSLOVNIH ŠKOLA I RAZVIJANJE STRUČNIH KOMPETENCIJA STUDENATA U TURIZMU}

\section{Sažetak}

Skorašnji trendovi rastaglobalizacije tržišta, tehnološkog napretka, internacionalizacije, privatizacije idrugih relevantnih promena, strateški menjaju kontekst u kome sve institucije društva rade i napreduju. Ovo utiče i na sektor visokog obrazovanja, a poslovne škole i fakulteti bi trebalo da budu bolje usklađeni sa stanjem koje diktiraju eksterni uslovi. U ovom dinamičnom i promenjivom okruženju, studenti, firme i druge zainteresovane strane treba da imaju znanje i veštine koje će im pružiti kompetenciju u skladu sa trenutnom ekonomskom situacijom i tehnološkim napretkom. Sektor turizma i ekonomija uopšte sve više zavise od aktuelnog znanja koje pruža adekvatnu kompetentnost u oblasti biznisa studentima, a pružaocima usluga kompetitivnu prednost. Prilagođavanje javnih visokoškolskih ustanova je važno zbog unapređivanja njihove tržišne pozicije na tržištu obrazovanja u biznisu, koje postaje sve više kompetitivno. Odnedavno je primetan sve veći broj privatnih škola za biznis, ali i za turizam - te škole su uvidele veliki potencijal za poslovni uspeh i zaradu na sve kompetitivnijem tržištu poslovnog obrazovanja, u okviru njegovog dinamičnog i konkurentnog okruženja. U prilog tome, škole biznisa moraju da se bave i problemom smanjenja budžetskih (javnih) sredstava za finansiranje njhovog poslovanja, što ih tera da traže dodatno finansiranje tako što će pružati dodatne obrazovne sadržaje i jačati svoju tržišnu orijentaciju. U debati o budućnosti obrazovanja u turizmu postoji razmimoilaženje između zahteva kurikuluma i očekivanja branše, što ukazuje na to da visoko obrazovanje treba da služi turizmu u budućnosti, tj. da pripremi studente za aktivniju ulogu u turističkim organizacijama i u njihovom sopstvenom unapređenju i prilagođavanju različitim konkurentnim uslovima. Da li kurikulumi poslovnih škola prate razvoj najskorijih ključnih trendova u branši? Glavni cilj ovog rada je identifikacija ključnih aspekata dinamičke adaptacije visokog poslovnog obrazovanja i obrazloženje moguće veze između razvoja profesionalnih kompetencija studenata na polju turizma i profesionalnih zahteva organizacija u ovoj branši. U radu ćemo koristiti komparativni metod (pregled i poređenje turizmoloških programa odabranih fakulteta u određenim zemljama bivše Jugoslavije, kao i takav pregled i poređenje bez obzira na eventualnu akreditovanost) i benčmark analizu koji će nam pomoći da nađemo razlike u dostignutim profesionalnim kompetencijama studenata određenih fakulteta i da ih uporedimo sa analognim kompetenncijama studenata vodećih fakulteta centralne Evrope u oblasti turizma.

Ključne reči: stručna kompetentnost studenata, obrazovanje u turizmu, tržišno usmerenje javnih institucija visokog obrazovanja, globalizacija, privatizacija visokog obrazovanja

TIMS Acta (2016) 10, 53-62

In the modern global economy, where the relationships between companies and countries are increasingly reflected in a more competitive nature of their response to external challenges - thus competitive capabilities are becoming a key instrument for the development of their market, economic and political power in a global context. As part of this process, knowledge and education are becoming increasingly important competitive resources, while also getting a distinct character of market goods. On the other hand, the present company predicaments (e.g. economic and financial crisis, environmental pollution, increasing disparities in levels of development of countries, etc.) represent new challenges for developing skills, which would provide answers for developmental issues of a modern society in the context of reinforced globalization of economies and markets, changing lines of economic and political power of countries, the 
necessity for sustainable development and greater social responsibilities of economic operators, which should be reflected in the evaluation of strategic frameworks of business schools, and in their policy, and developmentoriented adaptation of their values, research and educational efforts.

It is becoming clear that the creation and application of knowledge in social processes, and ensuring the competitiveness, are of key importance not only for economic well-being of individuals, but also for the market position of companies and welfare of the modern society and the state. Education and lifelong learning have become key factors in the accumulation of human capital (knowledge, values, skills, experience, talent, intuition, creativity...) and a central leverage of each country's economic growth. University business schools thus play an increasingly important role in a turbulent global environment and are becoming a crucial element of a knowledge society, including the field of tourism education.

Economic, political, socio-economic and other changes are manifested in all areas of global economy and processes in society, and, hence, these changes can be felt especially in the existing school system at all levels of formal education. With the actualization of the objectives of the Bologna Process, higher education in particular, is experiencing major changes. The demands and expectations of key stakeholders are changing; there is a growing need for additional formal education, upgrading of skills and technical education; Lifelong learning is becoming a constant in the process of strengthening professional skills and competencies of each individual in a society. Issues related to globalization, internationalization, dynamic response, positioning, market orientation, social responsibility, etc., are of key importance for strengthening the competitiveness of enterprises and the development of their critical success factors in an increasingly competitive global market and locally, which also applies to the tourism business and tourism education providers that are clearly a part of the global market.

\section{Higher education in the field of tourism}

Tourism industry is becoming one of the fastest growing economic sectors in the world. Tourism sector is considered as a key for the development of socioeconomic progress of a country and plays a significant role in international commerce and it is one of the main economic sources for developing countries (Frank, 2002; as cited in Nagarjuna \& Kallarakal, 2014, p.738).

In the European economy, tourism today represents a key sector, generating over $10 \%$ of EU GDP and is employing 9.7 million citizens in 1.8 million businesses (EC, 2010). Jobs in the tourism sector are especially attractive for the young workforce, which faces a $23.5 \%$ unemployment rate. According to European Commission (2013), there are tens of thousands of jobs currently available in the tourism sector across Europe, which could provide work for this young unemployed people, other workforce and also for (future) graduates of hospitality and tourism because, currently, there are all together more than 26 million Europeans out of work. Europe remains one of the favorite tourist destinations, despite the economic crisis. International tourist arrivals in Europe grew by 5 \% during the first half of 2013. Because of the growth of the tourism sector, tourism education is very important for tourism industry and the hospitality.

The major function of tourism sector depends on human resources, and the quality of human resources is very important for the success of tourism business. Tourism education plays a vital role for the development of human capital; it contributes to economic development of tourism sector, helps to improve the competitiveness of tourism business and increases the customers' satisfaction level. As we see, tourism education has a significant impact on the industry and that is why it is necessary for tourism education providers to follow the changing needs of industry (Nagarjuna \& Kallarakal, 2014, p.738).

Tourism education began as a development of technical/vocational schools in Europe, where students were trained in critical areas of hospitality and business (Morgan 2004, p. 94; Tribe, 2001, p. 447). Interest and demand from the public and private sectors impelled a rapid growth of tourism studies 
and the rise and development of tourism education at both the undergraduate and graduate levels. Hence, tourism education institutions established or expanded their tourism programs and included the business knowledge and skills that are nowadays required for the employability in this industry into their curriculums (Jameson-Charles, 2012, p. 145; Tribe, 2001, p. 447; Wattanacharoensil, 2013, p. 9).

Market orientation of education institutions, student competencies and vocational education and training

Meeting the needs of the industry and preparing students for employment are two important challenges for tourism and hospitality education providers offering knowledge and training (Owusu-Mintah \& Kissi, 2012, p. 522). Namely, education and employment of skilled professionals are making a positive contribution to the creation of wealth and quality of life, through graduates who are, as competitive and quality employers, able to contribute to both organization and the society (Frank, 2002; as cited in Nagarjuna \& Kallarakal, 2014, p.738). On the other hand, the main objective of tourism education programs is also to meet the needs of businesses operating in tourism, fostering students' professional career ambitions and professional goals of business schools' education staff.

An increasing level of criticism about the relevance of the higher education system implies that its institutions do not put enough effort to work and to collaborate with the industry - that they are not market oriented (enough) and relevant for firms' business operations. There is also a lack of cooperation between tourism educators and tourism industry in tourism sector (Bradshaw, 2011; Ivory et al., 2006).

Tourism education market, viewed globally, is subject to the trend of supply concentration and high competition between tourism education providers. Increased competition and global economic conditions require that schools should increasingly become more market-oriented. In this changing environment only those can survive, who take on an entrepreneurial mindset, openness to innovation, flexibility and, of course, change. Market environment and the public are becoming increasingly critical to tourism education, particularly in terms of real value added for business 'clients'. Therefore, the participation of the company and its wider surroundings of tourism education providers and formation of such programs are important, so that the company can earn benefits and that it can be of greater interest to its customers. In this way, the providers of knowledge have a lot to gain - new students, collaboration with practice, financial support to the economy, visibility, etc.

The demands of the economy or employers are also changing. The economy is increasingly dependent on knowledge, with which students acquire appropriate qualifications to receive and use information, and ultimately the appropriate awareness of the fact that knowledge is to be renewed. The latter is in particular important, because we know that in this day and age of constant technological and economic advances, knowledge, education and training are "are rapidly outdated". In addition to basic theoretical knowledge, specific technical and practical skills are expected from potential associates, as well.

Thus, a willingness for continuous updating on achieved areas of expertise and ability, and will power to conquer new knowledge outside of educational attainment is important, as well, whenever they are felt necessary for a future career of an individual. Thus, it is expected from every education provider that in addition to theoretical knowledge in specific fields of study, their programs also provide students with enough practical and communication skills and information knowledge, which are the key practical competencies in today's modern information society. Therefore, an often-asked question is: Do graduates of tourism and hospitality education programs possess the needed competences?

Goodman, Sprague, Kang, Wu and Gould (as cited in Millar et al., 2010) argued that industry professionals often claim that what educators teach in the classroom is outdated Hospitality and tourism products, technology, the workforce, and customers are constantly changing. As a result, relevant competencies of students and graduates evolve (Millar et al., 2010). The employers look for: overall intellectual ability, IT skills, oral and written communication skills, language skills (including good use of English plus other foreign languages), work spirits and 
ethics, flexibility, team working and leadership, tourism and hospitality knowledge skills (Nagarjuna \& Kallarakal, 2014, p.739; Thomas, 2007). Tesone and Ricci are saying that the most desired competencies include: teamwork, communication skills, guest service skills, professional appearance, understanding of industry expectations, etc. (as cited in Nagarjuna \& Kallarakal, 2014, p.739). Tourism industry looks for quality human resources who possess this competences and knowledge, and to achieve those, the university faculty and industry professionals must work together to ensure that. Industry professionals should be present in education process as lecturers and guest lecturers, as providers of student vocational training and they should also be involved in the designing of the curriculum (which should meet the needs of the industry).

Vocational education and training (VET) is an essential part of EU policy. Vocational education and training has a key economic function in up-skilling and integrating young people into the labor market and in providing high quality technical skills (Peter, 2013).

Vocational education and training and internship are very crucial components of most curricula, not only in tourism and hospitality education, but in every tertiary education institution (Owusu-Mintah \& Kissi, 2012, p. 522). According to Gunlu and Usta (2009; as cited in Owusu-Mintah \& Kissi, 2012, p 523) VET and internship in the tourism and hospitality industry provide undergraduate students with an enormous real world industry experience, where the students find the opportunity to update their knowledge and improve upon the skills that they have acquired whilst at college.

Thus student in some developing countries still may not get enough VET or internship, it is important to include it in education process, because (Inui et al., 2006, p. 26-27):

- as a result of internships and industry specific education, strong connections with the industry emerge;

- $\quad$ students benefit, they are very employable;

- students obtain management knowledge, experience and related interpersonal skills;

- it increases the ability of students to critically reflect on the tourism business (Tribe, 2001; as cited in Inui et al., 2006, pp. 26-27). Analysis of VET and training, market orientation and graduate competencies in some of chosen developing countries of former Yugoslavia, has been done in following research.

\section{Method}

The approach adopted in the theoretical part of this paper is descriptive; describing the facts of processes and phenomena in the European market providers of higher education in the field of tourism - in terms of their market orientation and the relationship between market orientation programs with vocational training of students, competence and acquired students skills pursuing careers in the tourism industry and the need of this institutions to adapt to requirements of the labor market in the tourism industry.

In the second part, we analyzed chosen faculties (Table 1) from countries of former Yugoslavia (Slovenia, Croatia, Bosnia and Herzegovina, Serbia, Montenegro and Republic of Macedonia). In each country, we chose then one faculty. Selection criteria for choosing a faculty was based on an initial review of international and national ranking charts, national visibility of the institution as top brand institutions.

Using comparative method, compilation method and benchmarking analysis, we determined a cause and effect relationship between selected aspects and variables respectively. In the comparative analysis, the following variables were used:

- General information on the institution (no. of years of operation, type of institution, status of institution, the reputation of the institution in the national / international context)

- Vocational training of students (mandatory VET, no. of hours of practice, the final report on VET, agreements with companies to realize the practice, the possibility of obtaining certificates, the possibility of foreign language courses (outside the regular curriculum))

- Market orientation (as defined in the vision and/or mission statement, and in the description of the programs included in the curriculum, research activities for the market/ economy, the integration of market/economy 
Rosi, M., Jurše, M. - Market orientation of bussiness schools in tourism

2016. Fakultet za sport i turizam, Novi Sad, TIMS Acta 10, 53-62

stakeholders in shaping curricula, another link with the market).

Data collection was limited to documents accessible in the public domain from publicly available sources, such as the institutional websites of the Universities/Faculties, which were searched and browsed systematically. The chosen method was constrained by the available resources and data from the websites.

Table 1. List of analyzed faculties from the countries of former Yugoslavia, Austria and UK

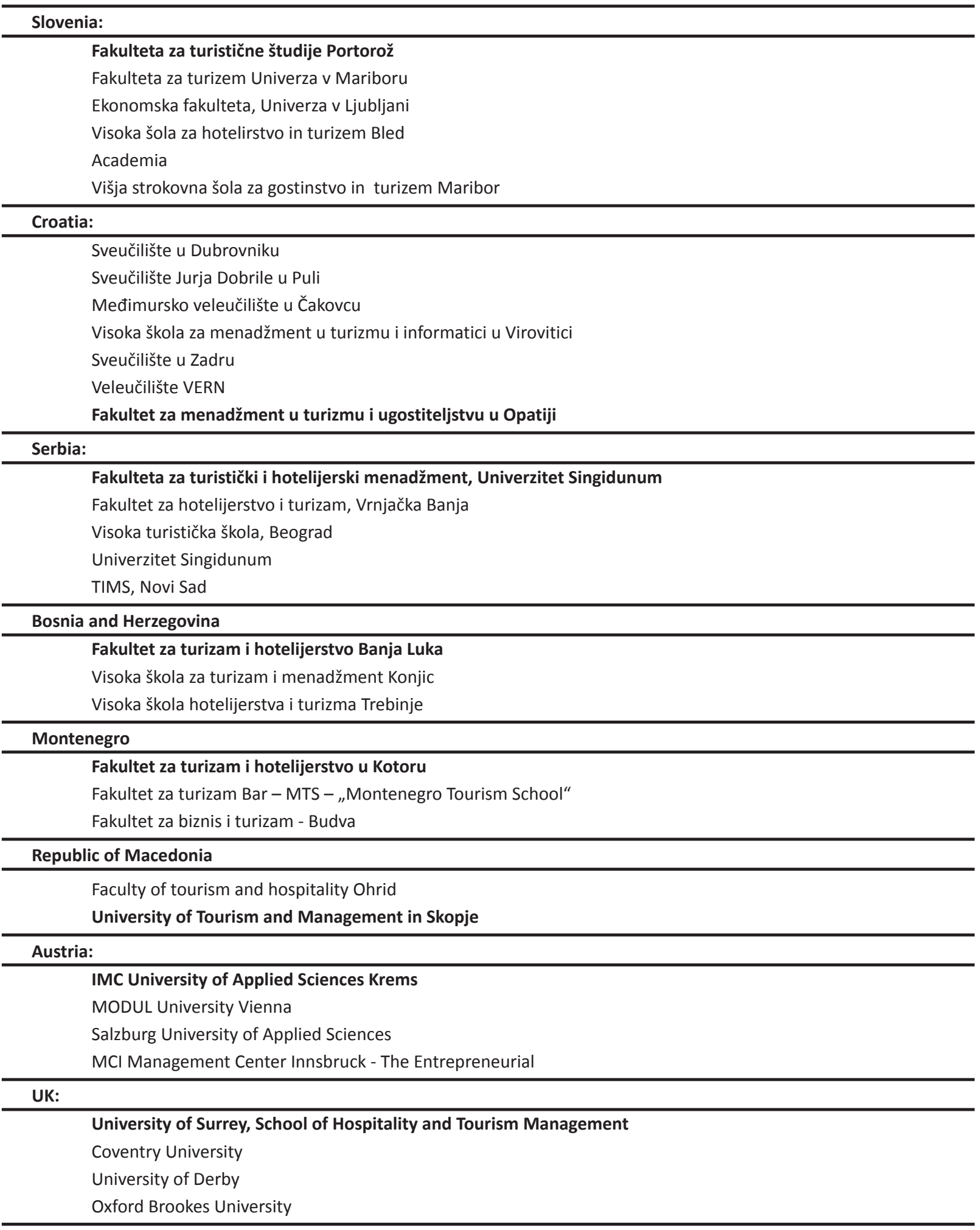




\section{Results}

With benchmarking method, we analyzed internal performance of chosen faculties from each country of former Yugoslavia and compared them with the selected top European faculties, identifying processes and approaches of high performing vocational training system. In the following, we provide some key results (for chosen variables):

- Variable: No. Years of operation (Existence years):

All compared faculties from countries of former Yugoslavia (in following ex YU) are young faculties, within between 10-15 years of existence. Exception is one faculty from Croatia that has been operating in the field of tourism for over 50 years.

- Variable: Type of Institution and the status of Institution

Two of the faculties of ex $Y U$ involved in the comparison have the status of private institutions, others are public. All faculties are members of the university.

\section{- Variable: Vocational/Professional Training}

The obtained data from the faculties' websites show that all faculties offer the obligatory vocational/ professional training for students integrated into the curriculum. Number of hours of practice varies between countries, ranging from 160 hours to 350 hours. Students practice is carried out in the last two years of study.

- Variable: Report of the practice agreements with companies for the realization of practice

From the analysis of the data available on the faculties' website, we tried to determine whether students must submit a written report about vocational training. We obtained this information from the web for only two faculties, namely, that students must write a report about their finished practical training in a selected organization. For other faculties, this data was not available on their web pages. In obtaining information from websites about agreements with companies for realization of students' practical training, we did not find any data for four faculties. It was evident from the contents of the website that only two schools had signed agreements with companies for realization of student practical training.

We were also interested in learning whether the selected faculties offer their students additional opportunities to obtain certified skills (foreign languages, tour guide course and other courses). Among the contents on the websites, it is clear that four of the six faculties do have the opportunity to gain various certificates, while two of the faculties do not have this information on their websites. The same conclusion goes for foreign language learning (outside the regular curriculum), where there is a variety of languages available to learn (from Italian, German, English, Spanish, French to Russian language).

\section{- Variable: Market orientation}

We determined whether the selected faculty from ex YU had recognized market orientation in their vision or mission. We found out that all compared faculties do include market orientation aspects in their visions or missions.

Analyzed data from faculties' web pages show that only about half of the faculties have market orientation included in the description of study programs; only one faculty reflects this in the curriculum.

- Variable: Research for the economy, economic integration in the curricula creation, other links with industry

Important aspects of market orientation of faculties are research activities, carried out by the faculties for economy/industry. All analyzed faculties collaborate with the business world in the context of research activities and they also involve key stakeholders from external businesses and institutions in the economy in other activities (co-organization of conferences, lectures of representatives from the economy, etc.). 


\section{Discussion}

As it can be seen from the theoretical part of this paper, authors increasingly mention the need to integrate the key stakeholders from economy into the design of business schools' curricula and learning content. Unfortunately, the data which would show the involvement of the business world stakeholders in their curricula and learning content development, was not obtained in any of the websites of selected faculties.

After the comparison of the selected faculties of the former Yugoslavia, we identified two top faculties in the field of tourism and hospitality - for the purpose of benchmarking analysis. We chose one faculty from Austria and one from the UK respectively, and both of them are listed as top faculties in the field of tourism and management education in Europe (according to Keystone Academic Solutions, 2015). For the purposes of our analysis, we used data obtained from faculties' web pages and links on these web pages.

Unlike selected faculties from ex YU (with the exception of the Croatian faculty), selected top faculties worked in the field of tourism education for over 40 years (Austria and the UK faculty over 50 years). The Austrian faculty is a private and independent faculty, while the UK faculty is public and a part of State University.

All faculties (from ex YU, Austria and UK) have in common that students have compulsory vocational/ professional training, however, on the other hand while standing out, in the UK faculty students must undergo the practice in the duration of 46 working weeks or, in summation, approximately 1840 hours. In the Austrian school, the number of training hours is halved; i.e. approximately 704 hours. Compared with the selected faculties of the ex YU, there are discrepancies. They require less vocational training working hours; the highest volume of hours is required by the Croatian faculty ( 350 hours), which is by a half less than in Austria or five times less than in the UK.

Deviations in the scope of vocational/professional training of students come from the number of years of operation, where we can see that selected top faculties have existed for much longer (more than 40 or 50 years) than the selected faculties from the ex-Yugoslavia countries (except Croatia), which has operated in the field of higher education in tourism for about 15 years. Variety in the scope of vocational/professional training of students also comes from market orientation point of view. Selected top faculties from Austria and UK are more market oriented as compared to faculties from ex-Yugoslavia, because, in both benchmarking schools, their market orientation is:

- clearly defined and highlighted in the mission and vision;

- clearly defined in the description of the programs;

- included in the curriculum.

After analyzing the available data from faculties' websites, it is evident that faculties from Austria and UK display a strong focus on integrating the faculty with the economy and the explicit and clearly defined participation in the economy and vice versa. Both faculties offer on their web pages data about research or the economy, joint projects and other important links. They also put emphasis on involving key stakeholders from economy in shaping the student curricula.

If we compare the top faculties with selected faculties from the ex-Yugoslav region (in the context of available data on their web pages), we can see that they both show more emphasis on vocational/ professional training of students, as this is evident from the scope of working hours. It is evident that both top faculties maintain a long list of agreements formed with mentoring companies (at the UK faculty they have more than 2000) and important links with the industry. Their features are also possibilities for additional education of students - in terms of obtaining certificates and courses in foreign languages, where the choice is much greater than in the faculties of former Yugoslavia.

Chosen top faculties emphasize graduates competencies and their career opportunities. Both faculties offer information on web pages, about the level of employability of graduates and who their employees are. This data was not evident on the websites of the selected faculties of former Yugoslavia. 


\section{Conclusion}

Traditional faculties in the transition countries are placed against a new developmental challenge, namely how to be transformed into modern market-oriented academic schools in a situation where these countries are becoming increasingly vulnerable to the operation of market forces. There is a need for knowledge providers, to become more market oriented. Strengthening of competition among knowledge providers, which is a reflection of accelerated globalization, internationalization and the increasing mobility etc., have a major contribution to different mode of tertiary and business education. There is also an increasing number of private schools, who see the possibility of success and earnings in knowledge market. New providers of knowledge in the last ten years have created a dynamic and competitive environment of education, also for tourism and hospitality knowledge providers.

In paper, we examined the facts of processes and phenomena in the European market providers of higher education in the field of tourism and hospitality (in terms of their market orientation and the relationship between market orientation programs with vocational training of students). We have briefly analyzed the study programs of chosen faculties from countries of former Yugoslavia and by using benchmarking method we analyzed the internal performance of these faculties from each country of former Yugoslavia, comparing them with the selected top European faculties, identifying processes and approaches of the high-performing vocational training system.

In view of limited data access from faculties websites (available for the purposes of our exploratory analysis), we can conclude that the chosen faculties from the countries of the former Yugoslavia, in comparison with the best European faculties (from Austria and UK) are adapting the curriculum well for the requirements of the global market. With their market orientation, they follow economic trends, promote vocational/professional training of students and follow the requirements of potential employers. Market orientation is stronger in chosen top faculties and they both require a higher number of vocational training hours.
Tourism curriculum including vocational training is proposed for the purpose of bridging the gap and ensuring a higher quality tourism education in the future. Chosen faculties from countries of former Yugoslavia should therefore increase their market orientation and collaboration with tourism industry and maybe increase the number of obligatory vocational training hours.

For further and more detailed analysis, we will develop a questionnaire and include all representative faculties from the field of tourism in former Yugoslavia.

\section{REFERENCES}

Bradshaw, D. (2011). Business school strategy: Customer becomes king. Financial times, Financial Training.

de Onzono, S. I., \& Carmona, S. (2007). The changing business model of B-schools. Journal of Management Development, 26(1), 22-32.

European Commission, EC. (2010). Europe, the world's No. 1 tourist destination: A new political framework for tourism in Europe. Retrieved from http://eur-lex.europa.eu/legal-content/EN/ALL/; sessionid=vCnVTxxTyz3Qp83VKvyq4Rph6IJ9kPlhT53Gdh0Px0z5SY sCOJJt!-1928635100?uri=CELEX:52010DC0352 2014 May 13.

European Commission, EC. (2013). Strong tourism season gives Europe an economic boost and much needed jobs. 27 September. Retrieved from http://europa.eu/rapid/press-release_IP-13-878_ en.htm 2014 May 13.

Inui, Y., Wheeler, D., \& Lankford, S. (2006). Rethinking Tourism Education: What Should Schools Teach. Journal of Hospitality Leisure Sport and Tourism, 5(2), 25-35. doi:10.3794/johlste.52.122

Jameson-Charles, M. (2012). Tourism education from a relationship management perspective. Caribbean Curriculum, 19(2012), 145170.

Millar, M., Mao, Z., \& Moreo, P. (2010). Hospitality \& tourism educators vs. the industry: A competency assessment. Journal of Hospitality \& Tourism Education, 22(2), 38-50.

Morgan, J. (2004). From production line to drama school: Higher education for the further of tourism. International Journal of Contemporary Hospitality Management, 19, 91-99..

Nagarjuna, G., \& Kallarakal, T. K. (2014). Expectations of Tourism Industry on Competencies and Tourism Education. International Journal of Advanced Research, 2(1), 738-745.

Owusu-Mintah, S .B., \& Kissi, M. (2012). . Interdisciplinary Journal of Contemporary Research,

Peter, (2013). European cooperation in Vocational Education and Training (Europe 2020 strategy). Retrieved from http:// epthinktank.eu/2013/10/02/european-cooperation-in- 
Rosi, M., Jurše, M. - Market orientation of bussiness schools in tourism

2016. Fakultet za sport i turizam, Novi Sad, TIMS Acta 10, 53-62

vocational-education-and-training-europe-2020-strategy/ 2015 Sep 12.

Tribe, J. (2001). Research Paradigms and the Tourism Curriculum. Journal of Travel Research, 39, 442-448.

Wattanacharoensil, W. (2013). Tourism Curriculum in a Global Perspective: Past, Present, and Future. International Education Studies, $7(1), 9$.

Datum prijave rada: 15.12.2015.

Datum prihvatanja rada: 21.01.2015.

\section{Kontakt}

Maja Rosi, Fakulteta za turizem, Univerza v Mariboru

Cesta prvih borcev 36, Brežice, Slovenia

E-mail: maja.rosi@um.si

Milan Jurše, Ekonomsko-poslovna fakulteta, Univerza v Mariboru

Razlagova 14, 2000 Maribor,Slovenia

E-mail: milan.jurse@uni.mb.si 